\title{
Mindfulness and the Therapeutic Function of Education
}

\section{TERRY HYLAND}

Although it has been given qualified approval by a number of philosophers of education, the so-called 'therapeutic turn' in education has been the subject of criticism by several commentators on post-compulsory and adult learning over the last few years. A key feature of this alleged development in recent educational policy is said to be the replacement of the traditional goals of knowledge and understanding with personal and social objectives concerned with enhancing and developing confidence and self-esteem in learners. After offering some critical observations on these developments, I suggest that there are some educationally justifiable goals underpinning what has been described as a therapeutic turn. Whilst accepting that 'selfesteem' and cognate concepts cannot provide a general end or universal aim of education, the therapeutic function is more valuable and significant than is generally acknowledged. This claim is justified by an examination of the concept of 'mindfulness' that, it is argued, can be an immensely powerful and valuable notion, which is integrally connected with the centrally transformative and developmental nature of learning and educational activity at all levels.

To them I may have owed another gift,

Of aspect more sublime: that blessed mood

In which the burden of the mystery,

In which the heavy and the weary weight

Of all this intelligible world,

Is lightened-that serene and blessed mood

In which the affections gently lead us on ...

While, with an eye made quiet by the power

Of harmony and the deep power of joy,

We see into the life of things.

William Wordsworth—Tintern Abbey

\section{THE THERAPEUTIC TURN IN EDUCATION}

Richard Smith has suggested that 'our sense of what education can be stands to be enriched, not diminished, by a sufficiently nuanced 
appreciation of its connections with therapy' (Smith, 2002, p. 95), and a qualified role for this dimension of education has been advocated by Ruth Cigman (2004) and Kristján Kristjánsson (2007). Within educational debate in general the claim that educational policy and practice has been negatively influenced by a 'therapeutic turn' in recent years has been argued by a number of commentators (Ecclestone, 2004a, b; Hayes, 2003; Thompson, 2007). Kathryn Ecclestone, in particular, has expressed concern about the growing popularity of notions such as 'self esteem' and 'emotional intelligence' in educational circles. This has led to 'new professional activities in emotional management, life coaching, mentoring, counselling, and interventions to build self-esteem and make people feel good emotionally in the pursuit of motivation, educational achievement and social inclusion' (Ecclestone, 2004a, p. 11). Moreover, it is claimed that the 'professional and popular support for these ideas' is now so strong 'that they have become a new social and educational orthodoxy' (ibid.). More recently Kathryn Ecclestone and Dennis Hayes (2008) have collaborated on a book that charts the 'dangerous rise' of therapeutic education at all levels of the UK education system.

Hayes has advanced similar arguments in investigating recent policy trends in vocational education and training (VET) in the post-school sector. The proposal is that-alongside the 'triumph of vocationalism' over the last few decades-there has been a 'triumph of therapeutic education', a 'form of preparation for work' arising out of the 'changed nexus between work and education' (Hayes, 2003, p. 54). He goes on to explain that: "The new vocational skills that are required in the workforce are sometimes called "emotional" or "aesthetic" labour. If post-school students are being trained in personal and social skills as well as in relationships, this is training in emotional labour ... training in emotional labour ... requires and receives a personal and wholehearted commitment to workplace values' (ibid.). What results is a form of VET in which the pursuit of knowledge - and the values of 'rationality, objectivity, science and progress' - are replaced by a set of post-modernist relativistic values concerned only with developing 'self-esteem' (ibid.). The critique is deepened and widened with the claim that:

All that society can offer is therapy and therapeutic organizations and initiatives to help adjust to the low expectations they are now expected to have. This explains how the government can focus so much on "basic skills', an ill-defined idea that often includes personal qualities and attitudes. Talk about 'basic skills' means: 'Get used to having limited expectations and no aspirations' (p. 55).

This bleak picture is completed with the trenchant and dire warning that: 'As therapeutic education becomes the norm ... the individualized and fractious workforce will be replaced by a workforce of the future in which every worker will be concerned with enhancing their own self-esteem and that of others. This future is not going to be a new creative age ... The therapeutic future will be static and dull' (ibid.). 
In the context of the discourse on adult education theory and practice, Jane Thompson has expressed similar worries about the fact that:

In the popular wisdom of adult education practice it is certainly the case that ideas about confidence, emotional intelligence, and self-esteem are commonplace. The literature of funding applications, project reports and evaluation exercises are full of claims by policy-makers and practitioners alike that interventions targeted at so-called non-traditional learners and socially excluded groups give rise to increased confidence and self-esteem (Thompson, 2007, p. 303).

Such developments, Thompson argues, are dangerously misguided-not only because they neglect or marginalise some of the traditional core values of adult learning concerned with developing knowledge and understanding for active citizenship - but also in their tendency to suggest that 'developing confidence and self-esteem can remedy a wide range of personal and social problems' with the result that this 'distracts attention from the structural causes inequality ... and from the widening gap between rich and poor more generally' (p. 304).

\section{THERAPY AND EDUCATION: SOME CRITICAL OBSERVATIONS}

Does this dystopian vision of contemporary education and training accord with reality? More importantly, what do these claims about a therapeutic turn actually mean and are they justified against the background of recent trends in post-school education and training? More significantly, for the purposes of my particular concern with the importance of mindfulness in personal educational growth and development, do the new emphases amount to anything more than giving due and proper attention to the affective domain of learning?

I should begin by expressing a measure of agreement with some of the specific concerns voiced by critics of the alleged therapeutic turn in education. If it is, indeed, the case that traditional goals linked to knowledge and understanding are being replaced by personal and social skills for post-school students, this trend should be forcefully criticised and resisted. The alleged mutation of VET into some form of employability counselling also needs to be vigorously challenged, as does any transformation of the traditional social, political and cultural objectives of adult education into psychotherapy. Before completely endorsing this crusade, however, we need to ask whether the claims about the therapeutic turn are sensible, coherent and justified. There are two main ways of making sense of any such questions: through empirical investigation or by philosophical/conceptual analysis. I intend to examine the therapeutic arguments by means of each method in turn. 


\section{Empirical Considerations}

There is some truth to Frank Furedi's (2003) critique of contemporary society in terms of its fostering of a 'victim culture' in which a preoccupation with emotional well-being and self-esteem serves to anesthetise people in times of social and economic risk and uncertainty. We might accept that there is simply too much emphasis on personal counselling and individual rights and not enough on active citizenship duties and responsibilities in current times. It must also be acknowledged that - if all this is true-it is regressive and disempowering. What is difficult to discern, however, is how this putative change in general attitudes and ethos is influencing education trends to any great extent. Most of the actual examples cited by Ecclestone (2004a, b), for example, are drawn from the general field of counselling and the popular press, not specifically from educational contexts. She regrets the replacement of 'optimistic Rogerian ideas about humans' innate potential and drive for empowerment' with 'pessimistic images of people locked in cycles of social depression caused by emotional problems' (Ecclestone, 2004a, p. 13). If this were true, it would be most regrettable.

However, it could be argued that-apart from a highly theoretical, inspirational impact akin to that of Paulo Freire on adult literacy tutorsRogers has never had any practical influence on post-school learning, at least as far as the United Kingdom (UK) post-compulsory sector is concerned. I would suggest that the alleged pessimistic perspectives have no greater impact or influence on the business of learning and teaching in the post-16 sector in Britain.

Indeed, this picture of a post-compulsory sector dominated by objectives linked to emotional intelligence and self-esteem is not one that is easily recognisable. On the contrary, policy studies (Ainley, 1999; Hyland and Merrill, 2003) suggest that the key trends at this level over recent years have been the rise of undifferentiated skill-talk, an obsession with prescriptive learning outcomes and the dominance of competence-based education and training (CBET). The so-called therapeutic turn pales into insignificance alongside the damage wreaked by CBET and the behaviourist outcomes movement in the UK (see research by Roe, Wiseman and Costello, 2006) bringing with it the de-skilling of many occupations (including teaching), the downgrading of vocational studies and the rise to prominence of a predominantly utilitarian and one-sidedly economistic conception of the educational enterprise in general (Lea et al., 2003; Hyland and Merrill, 2003; Hyland and Winch, 2007). Emphasising affective goals and fostering motivation and confidence in learners is far less dangerous than suggesting that all that counts in education and training is providing bits of evidence to satisfy narrow, mechanistic performance criteria.

Moreover, given the fact that most learners in the post-school sector are either studying or increasingly preparing to re-sit secondary school graduation examinations these days (e.g. GCSEs and A-levels in the UK) or pursuing vocational qualifications, the notion that such programmes are more than marginally concerned with building self-esteem or emotional 
intelligence is difficult to accept (basic skills or 'skills for life' discussed below is, of course, extremely vocational and employment-led and has little to do with the affective domain). There is more than enough scope to argue that much of this post-16 learning is grossly deficient in precisely this affective area; it does not connect or engage sufficiently with the emotions, values and wider interests that learners bring with them to postcompulsory institutions (Hyland and Merrill, 2003). The increase in mental health and emotional/behavioural problems in the sector is now being acknowledged with a view to researching and implementing strategies to remedy the main problems (Warwick et al., 2008).

It is ludicrous to suggest that a sector that has been dominated for the last decade or so with ill-founded skill-talk and behaviourist CBET is somehow obsessed with affective objectives. It is true that certain features of competence-based learning have been perversely (mis-)matched with progressive, individualised and student-centred strategies (Hyland, 1999), but this pedagogic absurdity no longer confuses or misleads anyone working in the further and higher education sector. Moreover, it is difficult to make much sense of Hayes' idea that basic skills-a self-evident prerequisite for learning of any kind-is an example of the reduction of education to therapy. For learners, young or old, who achieved little at school and associate learning with anxiety, grief and failure, a 'therapeutic' concern with foundational skills, attitudes and motivations may be exactly what is called for.

In the absence of detailed evidence in the form of appropriate research surveys or case studies, the empirical arguments for the existence of a therapeutic turn are weak, and a reflective agnosticism on the issue seems to be justified.

\section{Philosophical Considerations}

A central slogan in the progressive education movement of the earlier $20^{\text {th }}$ century was 'we teach children-not subjects', and this was, as Robert Dearden (1968) suggests, a direct reaction to the drab authoritarianism and inhuman social utility of the elementary school tradition in England (graphically depicted and satirised in Charles Dickens' Hard Times and D. H. Lawrence's The Rainbow). What was to become the UK's paradigm text of the progressive movement- the Plowden Report published by the Department of Education and Science in 1967-described the ideal school environment as 'one in which children learn to live first and foremost as children and not as adults'. It was recommended that schools should set out to 'devise the right environment for children, to allow them to be themselves', and special emphasis was placed upon 'individual discovery, on first-hand experience and on opportunities for creative work' (Plowden Report, 1967, pp. 187-8).

Although there was always more rhetoric than reality (in a way similar to that surrounding the impact of Rogers and Freire on post-school education) about the claims that progressive philosophy was transforming 
English schools in the 1960s and 1970s (Hyland, 1979; Lowe, 2007), such ideas did inspire the open education movement in America as the earlier influences of Dalton and Dewey were re-discovered and applied to new times. Charles Rathbone, one of the leading open education exponents of the period, claimed that Plowden's views on the nature of childhood underpinned the 'open education ethic' that entailed treating children with 'courtesy, kindness, and respect ... valuing [the child] as a human being whose rights are no less valid than those of an adult' (Rathbone, 1971, p. 112). In a similar vein, the new openness in education was described as 'a way of extending the school's human dimension' (Pluckrose, 1975, p. 3) and, more grandly, an 'attempt to create a new human and social world' (Bremer, 1975, p. 18). In the stress on student-centeredness and individualised learning, such perspectives later came to influence post-school education (Hyland and Merrill, 2003) as well though-in an era of behaviourist outcomes-any such affective aims could never be more than marginal to the acquisition of qualifications for working life.

In the midst of all the rhetoric it is not difficult to recognise a number of fairly unexceptionable notions about the fact that education is surely about personal development as well as acquiring knowledge and skills, and that even R. S. Peters' (1966) liberal conception of education as the development of knowledge and understanding for its own sake must, in some sense, be linked to more general ends such as human happiness and flourishing or the promotion of a just community. To be sure, the subjectmatter of education cannot just be, as Alfred North Whitehead once grandiloquently put it, 'Life in all its manifestations' (Whitehead, 1962, p. 10) nor, as Dearden correctly argues, can the 'aim of education simply be happiness, quite without qualification' (Dearden, 1972, p. 111). However, as Dearden goes on to emphasise, there 'is no question of whether or not happiness is valuable ... the question is rather that of how important happiness is, compared with other values, in a specifically educational situation' (p. 109). Similarly, Smith suggests that 'self-esteem can usefully be admitted into our educational scheme of things as a significant good, but not one pursued directly, still less exclusively' (Smith, 2002, p. 99). For educational purposes, what needs to be attached to all-embracing external ends about self-esteem, happiness or human flourishing are internal objectives concerned with the development of knowledge, understanding, autonomy and values that will enable those being educated to construct and participate in communities that promote and reinforce such flourishing. The affective dimension of educational activity-linked to both processes in terms of stimulating learners' interests and motivation and also to content in the acknowledgement that knowledge and skills cannot be completely separated from human values and emotions - is arguably what is being highlighted in referring to the therapeutic function of education.

John Wilson has pointed out that there are many connections and overlaps between education and therapy. He observes that:

Education involves initiation into activities, forms of thought, etc. which conceptually must be ... worthwhile or justifiable. Different types of 
justifications, or different descriptions of the mode in which they are worth while, may apply to different activities or groups of activities. Thus some may be called 'therapeutic', others described as 'enlarging the personality'... These justification phrases may be said to represent the 'aims of education'; and 'therapeutic' or 'contributing to mental health', may represent one such aim (Wilson, 1972, pp. 91-2).

Peters (1972) also demonstrated the clear and distinct connections between human emotions, motivation and the sort of reasoning associated with the development of knowledge and understanding, and this seems to be what Smith is alluding to in arguing that to "say that we might make room for self-esteem without allowing it to take over the entire house of education or of therapy is to say that we need to see learning, personal identity, motivation and related matters through a wider lens' (Smith, 2002, pp. 99-100). Wilson is getting at something similar when he argues that "we can say that certain educational processes just are the same as some processes that increase mental health: that some forms of teaching are identical with some forms of psychotherapy' (Wilson, 1972, p. 89). The idea is that both learning (education) and therapy involve the development of knowledge, values, emotions, understanding, reason, skill, experience and insight, and both are equally necessary for accessing work, social relationships and the wider communities of practice that constitute the good life.

\section{THE NATURE OF MINDFULNESS}

In advocating and seeking to justify a form of therapeutic education along the lines outlined above, I want to draw attention to both the intrinsic and pragmatic value of the concept of 'mindfulness' (beautifully captured in the Wordsworth extract quoted at the beginning). This is a core concept in Buddhist philosophy and practice-traditionally the seventh strand of the eightfold path leading to nirvana and the end of suffering-and is currently attracting widespread attention in a large number of spheres far removed from its natural and original home. In the context of the Dharma (the Buddhist canon of teachings and precepts), mindfulness is of overriding importance.

Thich Nhat Hanh-the renowned Vietnamese Buddhist teacher and campaigner for world peace and justice-describes mindfulness as being 'at the heart of the Buddha's teachings'. It involves 'attention to the present moment' that is 'inclusive and loving' and that 'accepts everything without judging or reacting' (Thich Nhat Hahn, 1999, p. 64). Jon KabatZinn (1990; 1994) and associates have been largely responsible for transforming the original spiritual notion into a powerful and ubiquitous therapeutic tool based on forms of meditation and mindful practices. Mindfulness simply means 'paying attention in a particular way: on purpose, in the present moment and non-judgmentally' in a way that "nurtures greater awareness, clarity, and acceptance of present-moment reality'. Such practice-whether this involves breathing or walking 
meditation or giving full non-judgmental attention to everyday activities - can offer a 'powerful route for getting ourselves unstuck, back in touch with our own wisdom and vitality' (Kabat-Zinn, 1994, pp. 4-5). Such a simple idea has proved successful in a diverse range of contexts including the treatment of depression, addictions of various kinds, and the promotion of physical and mental health and wellbeing generally (Baer, 2006; Garfinkel, 2006).

Since there may be a tendency to associate mindfulness exclusively with passive inner experience it is important to look more closely at its constituent features in order to display the specifically educational implications. Kabat-Zinn offers a clear characterisation in terms of seven key aspects:

1) Non-judgmental-involving the assumption of an impartial witness of our own experience. When we begin paying close attention to the activity of our own mind, it soon becomes apparent that almost all thoughts and images are accompanied by a process of categorising and labelling in the form of noting some as bad and some as good. Instead of this constant judging-and the attendant favouring/ disfavouring of certain patterns-we are asked to let go of such mechanical reactions and just be with the experience of thinking itself.

2) Patience-an executive virtue in almost any context, in mindfulness work it means the wisdom not to strive or worry too much about external ends or goals, so that such constant planning and deliberating does not overwhelm our perception of the present moment. It is this unbidden mental restlessness that Schopenhauer described as the blind striving of the will and, interestingly, he also turned to Eastern spiritual practices to look for solutions (Hyland, 1985).

3) Beginner's mind-we are asked not to let our past experience and knowledge get in the way of our present thoughts and perceptions. The idea is to cultivate an attitude of seeing things as if the for the first time so as to be alive to unforeseen or previously unacknowledged possibilities in experience

4) Trust - the development of a basic trust in the importance and value of our own thoughts, feelings and experiences. This does not mean neglecting external forms of knowledge and authority but, rather, always, balancing these against our own authentic vision of the world (as perhaps we may do anyway, often very unmindfully).

5) Non-striving - if mindfulness is practised through forms of meditation it has no goals beyond itself thus is not a susceptible to constant criticism and revision. We are simply paying attention to anything that is happening and this is the only end. If mindfulness is applied to other activities-whether practical ones like driving a car or theoretical ones such as solving a problem or making a decisionthe ends of goals are inherent in these activities. Mindfulness simply assists in their achievement by directing attention only to the basic 
features and effective means whilst closing out extraneous influences.

6) Acceptance-this involves a willingness to see things as they really are, not as we would like them to be. It does not mean being passively resigned to tolerating present conditions but-by accepting the full reality of the present-allowing for change and development. Whether it involves our personal or our professional lives, acceptance leads to a facing up to rather than an avoidance of what we uniquely experience and perceive.

7) Letting go - attending to inner experience soon reveals a range of thoughts and images that we want to either avoid or hold on to. The tendency towards aversion or desire in terms of automatic, unreflective selection of states of mind-just as with the mind's natural proclivity to dwell on the past or plan for the future - is to be resisted in mindfulness practice. The idea is to simply watch thoughts and ideas appear and disappear without necessarily wanting to hold on to anything. Such letting go is perhaps the most difficult part of a practice that seems-on first inspection-to be so incredibly, almost naively, simple (see Kabat-Zinn, 1990, pp. 3338).

Like any process or activity that is concerned principally with introspection and a focus on inner thoughts and feelings, there seems to be a natural tendency to assign it a limited value because of its apparent passivity and subjective inward-looking character. Smith notes this in remarking that some sort of 'inward turn' is 'often (but wrongly) associated with therapy in general' (Smith, 2002, p. 95). However, mindfulness does seem to be able to deal with such criticisms effectively, particularly when the concept is interpreted within the context of its original home in Buddhist philosophy and practice.

The immense potential of paying close attention to our thought processes should not be under-estimated. In its normal state, the mind is often in flux as it fixes on one object after another in a random and dissipated manner. By 'cultivating mindfulness', the Dalai Lama reminds us, 'we learn first to become aware of this process of dissipation, so that we can gently fine-tune the mind to follow a more directed path towards the objects on which we wish to focus' (Dalai Lama, 2005, p. 160). It is important to note that such attention has 'a deliberate intention that helps us select a specific aspect or a characteristic of an object. The continued, voluntary application of attention is what helps us maintain a sustained focus on the chosen object. Training in attention is closely linked with learning how to control our mental processes' (p. 161). This controlwhich can be an end in itself in the therapeutic uses of mindfulness-is linked to the central Buddhist enterprise in the process of eliminating unhelpful and misleading conceptions of the self. There is, of course, a similar critical tradition in relation to the concept of selfhood in Western philosophy stemming from Hume's famous observation in his Treatise that 'I never can catch myself at any time without a perception, and never 
can observe anything but the perception' (Hume, 1964, p. 239). Within the Buddhist tradition the notion of 'non-self' is remarkably similar to both Hume and the social constructionist perspectives of more recent times. Brazier explains the position clearly in observing that the:

... Buddhist approach is neither to build nor to abase the self. It is to recognise the reality of our existential position in relationship with the world. It recognizes our dependency upon conditions, and especially upon our physical environment ... The teaching of non-self is not a denial of the existence of the person as a complex entity, functioning in a complex world. Non-self theory places people in dynamic encounter with one another and with the environment they inhabit. It acknowledges the everunfolding social process and the ways in which people provide conditions for one another (Brazier, 2003, p. 138).

\section{MINDFULNESS AND THE CRITIQUE OF THERAPEUTIC EDUCATION}

There seem to be two main criticisms of the therapeutic function of education and I will address each in turn, drawing on mindfulness conceptions and cognate ideas in the attempt to answer the principal concerns.

1) The emphasis on therapeutic objectives such as self-esteem, emotional intelligence, confidence and the like, is said to marginalise traditional goals linked to knowledge and understanding thereby disempowering learners. Philosophical answers-in the form of explicating links between educational and therapeutic processes-were outlined earlier, as were empirical considerations questioning the extent of this influence on learning and teaching as opposed to popular culture. I would argue that most educational activity — both at school but especially at postschool levels-is affectively impoverished and grossly deficient in its treatment of humanistic as opposed to economistic matters. The personal growth and development of learners-whether this is called fostering selfesteem, confidence or emotional intelligence-is an important educational objective, and the cultivation of mindfulness can assist in its achievement. As a dimension of the learning process, mindfulness practice can effectively link all forms of learning (perhaps especially the undervalued basic skills and vocational kinds) with the needs, interests and values of learners thus fostering engagement, motivation and that form of 'studentship' that, as Martin Bloomer and Phil Hodkinson (1997) have shown, is crucial in allowing post-16 students to make sense and take ownership of the various programmes they are following. The 'present-moment reality' developed through mindfulness is now widely acknowledged in educational psychology as not just 'more effective, but also more enjoyable' (Langer, 2003, p. 43) in many spheres of learning, and there is now a wealth of evidence aggregated through the Mindfulness in Education Network (http://www.mindfuled.org) about the general educational benefits of the approach. ${ }^{1}$ 
2) A related concern of critics of therapeutic education-particularly in adult education circles-is that the perceived inward-looking features associated with this activity severs the connections between learning and wider social and political issues. Thompson, for example, is worried that 'lifelong learning has given up on teaching an understanding of the world, let alone trying to change it', and that there is 'every encouragement for the belief that because you cannot change the world, you must strive to change yourself' (Thompson, 2007, p. 302). Such claims, if true, would indeed be a cause for concern but I think they are misguided and unduly pessimistic. The world can only be changed by people and often the reflective capacity to change ourselves is precisely what is required before any wider social change is possible. The power and potential of mindfulness in engaging with a wide range of such issues has been demonstrated both by its medical and psychotherapeutic applications (Williams et al., 2007) and also through work by socially engaged practitioners (Garfinkel, 2006).

The letting go of self in mindfulness practice results-interestingly in terms of the standard criticisms of the passive navel-gazing involved in fostering self-esteem and related qualities-in people stopping 'relying on self-power and starting to rely more on other-power' (Brazier, 2003, p. 143). This is the definitive conception of empowerment that is prized so highly by adult educators concerned with social movements and is fully realised in the impact of Buddhist mindfulness in countries around the world. In the form of 'socially engaged Buddhism' (a movement pioneered by Thich Nhat Hanh-see Garfinkel, 2006), mindfulness practices are now employed in prison education, peace negotiations and the re-generation of village communities in deprived areas around the world. As Garfinkel explains, such practice is 'being applied to augment mental and physical health therapies and to advance political and environmental reforms. Athletes use it to sharpen their game. Through it, corporate executives learn to handle stress better. Police arm themselves with it to defuse volatile situations. Chronic pain sufferers apply it as a coping salve' (Garfinkel, 2006, p. 3).

\section{CONCLUSION: MINDFULNESS AND THE AIMS OF EDUCATION}

Smith (2002) is quite correct to locate self-esteem amongst the legitimate aims of education, and I have tried to provide a justification for a more general therapeutic function based on mindfulness. Mindfulness serves to remind us that-in addition to the important goals of developing knowledge, understanding, vocational skills and the critical examination of issues of inequality, prejudice and social exclusion - there are people with identities, needs, values and life stories who are engaged in the struggle to deal with all this. Much current educational practice fails to capture this struggle and does not touch the emotional grief and suffering involved. The Buddha famously said that he taught one thing and one thing only: 'suffering and the cessation of suffering' (Segal, 2003, p. 165), 
and this core teaching is of inestimable value in our current educational climate. In helping us to let go of the often mindless and restless striving that lies at the heart of our mental processes and habit-driven behaviour, mindfulness prepares the way for genuinely rich and deep learning and the journey from self-obsession to a fuller engagement with life and with others. There can be few worthier educational ideals. As Thich Nhat Hanh puts it:

Mindfulness helps us look deeply into the depths of our consciousness ... When we practice this we are liberated from fear, sorrow and the fires burning inside us. When mindfulness embraces our joy, our sadness, and all our mental formations, sooner or later we will see their deep roots ... Mindfulness shines its light upon them and helps them to transform (Thich Nhat Hanh, 1999, p. 75).

Correspondence: Terry Hyland, Arts, Media \& Education, University of Bolton, Eagle Campus, Bolton BL3 5AB, UK.

E-mail: t.hyland@bolton.ac.uk

\section{NOTE}

1. There is also an established centre for mindfulness teaching and research at the University of Wales, Bangor (see: http://www.bangor.ac.uk/imscar/mindfulness).

\section{REFERENCES}

Ainley, P. (1999) Learning Policy (London, Routledge).

Baer, R. A. (ed.) (2006) Mindfulness-Based Treatment Approaches (San Diego, CA, Elsevier).

Bloomer, M. and Hodkinson, P. (1997) Moving into FE-The Voice of the Learner (London, Further Education Development Agency).

Brazier, C. (2003) Buddhist Psychology (London, Robinson).

Bremer, J. (1975) A Matrix for Modern Education (Toronto, McClelland and Stewart).

Cigman, R. (2004) Situated Self-Esteem;, Journal of Philosophy of Education, 38.1, pp. 91-105.

Dalai, Lama (2005) The Universe in a Single Atom (London, Little, Brown).

Dearden, R. F. (1968) The Philosophy of Primary Education: An Introduction (London, Routledge and Kegan Paul).

Dearden, R. F. (1972) Happiness and Education; in: R. F. Dearden, P. H. Hirst and R. S. Peters (eds)(op. it.).

Dearden, R. F., Hirst, P. H. and Peters, R. S. (eds) (1972) Education and the Development of Reason (London, Routledge and Kegan Paul).

Ecclestone, K. (2004a) Developing Self-esteem and Emotional Well-being-Inclusion or Intrusion?, Adults Learning, 16.3, pp. 11-13.

Ecclestone, K. (2004b) Learning or Therapy? The Demoralisation of Education, British Journal of Educational Studies, 52.2, pp. 112-137.

Ecclestone, K. and Hayes, D. (2008) The Dangerous Rise of Therapeutic Education (London, Routledge).

Furedi, F. (2003) Therapy Culture: Creating Vulnerability in an Uncertain Age (London, Routledge).

Garfinkel, P. (2006) Buddha or Bust (New York, Three Rivers Press). 
Hayes, D. (2003) The Changed Nexus Between Work and Education;, in: J. Lea et al. (eds) Working in Post-Compulsory Education (Maidenhead, Open University Press).

Hume, D. (1964 edn.) A Treatise of Human Nature (London, Everyman), Vol. 1).

Hyland, T. (1979) Open Education-A Slogan Examined, Educational Studies, 5.1, pp. 35-41.

Hyland, T. (1985) Unhappiness and Education-Some Lessons from Schopenhauer, Educational Studies, 11.3, pp. 219-229.

Hyland, T. (1999) Vocational Studies, Lifelong Learning and Social Values (Aldershot, Ashgate).

Hyland, T. and Merrill, B. (2003) The Changing Face of Further Education (London, RoutledgeFalmer).

Hyland, T. and Winch, C. (2007) A Guide to Vocational Education and Training (London, Continuum).

Kabat-Zinn, J. (1990) Full Catastrophe Living (London, Piatkus).

Kabat-Zinn, J. (1994) Mindfulness Meditation for Everyday Life (London, Piatkus).

Kristjánsson, K. (2007) Justified self-Esteem, Journal of Philosophy of Education, 41.2, pp. 247 261.

Langer, E. (2003) A Mindful Education, Educational Psychologist, 28.1, pp. 43-50.

Lea, J. et al. (eds) (2003) Working in Post-Compulsory Education (Maidenhead, Open University Press).

Lowe, R. (2007) The Death of Progressive Education: How Teachers Lost Control of the Classroom (London, Routledge).

Peters, R. S. (1966) Ethics and Education (London, Allen and Unwin).

Peters, R. S. (1972) The Education of the Emotions, in: R. F. Dearden, P. H. Hirst and R. S. Peters (eds) (op. it.).

Plowden Report (1967) Children and Their Primary Schools (London, HMSO), Vol. 1.

Pluckrose, H. (1975) Open School, Open Society (London, Evans Brothers).

Rathbone, C. H. (1971) Open Education: The Informal Classroom (New York, Citation Press).

Roe, P., Wiseman, J. and Costello, M. (2006) Perceptions and Use of NVQs: A Survey of Employers (London, Department for Education and Skills).

Segal, S. R. (2003) Encountering Buddhism: Western Psychology and Buddhist Teachings (Albany, State University of New York Press).

Smith, R. (2002) Self-Esteem: The Kindly Apocalypse, Journal of Philosophy of Education, 36.1, pp. $87-100$.

Thich Nhat Hahn (1999) The Heart of the Buddha's Teaching (New York, Broadway Books).

Thompson, J. (2007) Changing Ideas and Beliefs in Lifelong Learning?, in: D. Aspin (ed.) Philosophical Perspectives on Lifelong Learning (Dordrecht, The Netherlands, Springer).

Warwick, I., Maxwell, C., Statham, J., Aggleton, P. and Simon, A. (2008) Supporting Mental Health and Emotional Well-Being Among Younger Students in Further Education, Journal of Further and Higher Education, 32.1, pp. 1-13.

Whitehead, A. N. (1962) The Aims of Education (London, Ernest Benn Ltd.).

Williams, M., Teesdale, J., Segal, Z. and Kabat-Zinn, J. (2007) The Mindful Way Through Depression : Freeing Yourself from Chronic Unhappiness (New York, Guilford Publications). Wilson, J. (1972) Mental Health as an Aim of Education, in: R. F. Dearden, P. H. Hirst and R. S. Peters (eds)(op. cit.). 